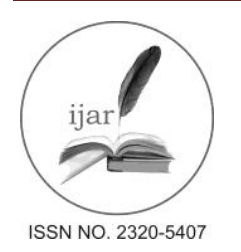

Journal homepage: http://www.journalijar.com
Journal DOI: 10.21474/IJAR01

INTERNATIONAL JOURNAL

OF ADVANCED RESEARCH

RESEARCH ARTICLE

\title{
PHYSICO-CHEMICAL AND ANATOMICAL ANALYSIS OF Bambusa assamica Barooah \& Borthakur OF ASSAM AND NORTH-EAST INDIA.
}

"Sanjib Brahma", Birendra Kumar Brahma ${ }^{2}$.

1. Head of the Department, Botany, Science College, Kokrajhar, Assam, India, 783370.

2. Project Scientist, Bamboo technology, Bodoland University, Assam, India.783370.

\section{Manuscript Info}

\section{Manuscript History:}

Received: 15 April 2016

Final Accepted: 29 May 2016

Published Online: June 2016

Key words:

Bambusa assamica ; Physico-

chemical and anatomical analysis of bamboo; Assam and North -East

India; AAS-analysis of elements;

Fibre length; Kokrajhar district of BTC.

*Corresponding Author

Sanjib Brahma.

\section{Abstract}

Searching of forest based wood substitute is the broad objective of analytical study of bamboo species. The application of bamboo can reduce the most exploited timber based wood uses. Bamboo can be treated as fast growing wood species as this plant is ready for application within a minimum of one and half year. The utilisation of bamboo in Assam and North-east India is ancient. Bamboo sometimes called poor man's timber is now focused as the timber of future. The utilisation of bamboo in this part of the country is immense and multiple in dimensions.

Physico- chemical and anatomical compositions of Bambusa assamica a lesser known bamboo species of Assam have been studied in this paper. The basic aim of this study is to document important physico-chemical and anatomical contents of this bamboo. The knowing of physico-chemical and anatomical content of this bamboo is the integral part for application of this bamboo. This study of Physico-chemical and anatomical composition will provide basic information about the possible application of this bamboo and will extend its dimensions of application from traditional to industrial uses.

Copy Right, IJAR, 2016,. All rights reserved.

\section{Introduction:-}

North-eastern India comprising the states of West Bengal (North Bengal, Himalaya), Sikkim, Arunachal Pradesh, Assam, Nagaland, Mizoram, Manipur, Meghalaya and Tripura has more than 50 per cent bamboo species reported from India $[2,3,9]$.

Bambusa assamica which is a comparatively small size bamboo is traditionally used in many purposes. This bamboo has erect culms measuring $5-12 \mathrm{~m}$ height, $1.5-3 \mathrm{~cm}$ in diameter, not very straight, white powdery when young, glabrous, green on maturity; nodes prominently thickened; internodes 15-40cm long, walls3-4mm thick[1]. Bamboo basketries are one of the economic activities among certain communities of Assam and North-Eastern states. The tribal population of Assam and North-east of India uses 100s of different bamboo basketries in their day to day activities. Bambusa assamica is popular among the rural community people, because this bamboo is suitable for making of much basketry. Beside basketries this small size bamboo is even used in many building and construction work.

Bamboo has been the focus of research and development in recent years. Bamboos are considered to be among the fastest growing plant on earth. This makes them the best possible alternative to replaced timber as a source of cellulose in the future [8]. However, study on cultivated bamboo stands has so far mostly confined to selected species in silviculture and fertilizers application to enhance growing [1]. Studies to obtained information on physicochemical and anatomical properties of many less utilised bamboo species are still wanting. 
The importance of Bamboo to rural community can hardly be over stressed since it is a versatile, multipurpose, forest species which contributes valuably towards the human economy providing a variety of goods. Even in today's world of plastic and steel this fastest growing species has not only maintained its place as a contributor of daily needs but also attained significance as an industrial raw material [9].

Bamboos are used for many different purposes. Often only some species are suitable or preferred for certain uses, whereas other species are neglected or even disregarded. What are the criteria for such a selection? It is generally known that restrictions in processing and utilisation are often related to unsuitable properties. Therefore a thorough understanding of the relation between structures, properties, behavior in processing and product qualities is necessary for promoting the utilization of bamboo [7].[5] pointed out that bending stress decreases with the height of the culm bud the modulus of elasticity increases with the latter. [6] reported that the fibre size in the middle part of the part of culm is greater than in the bottom and the top, and that the outer part of the culm has longer fibre than the inner part.

Thick -walled fibres adversely affect the bursting strength, tensile strength, and folding endurance of paper. The paper manufactured from thick-walled fibres will be bulky, coarse surfaced, and containing a large amount of void volume [8].

Since the common users have traditional idea on the bamboo species relating to durability and applicability which is based only on size of bamboo, hence our aim is to study this bamboo and clarify the users' concept basing on its chemical and anatomical contents [4].

\section{Materials and Methods:-}

For these studies the bamboo sample was collected from 5 (five) different localities of Kokrajhar district of BTC, Assam, India. Five (5) individual bamboo culms were harvested for studies. The sample collection was done during the month of May-June 2015.The method for studying different contents were followed the standards of American Society for Testing and Materials (ASTM) with slight modification whenever needed. The sample sizes were prepared accordingly to perform different test.

\section{Study of Physico-Chemical characters:- \\ Moisture content:-}

Moisture content was determined by using the sample block $10 \mathrm{mmX} 10 \mathrm{~mm}$ thickness. Fresh weight was taken immediately after the collection of sample and dried weight was taken after the sample block was oven dried at $105 \pm 2^{0} \mathrm{C}$ for 48 hours. Desiccator was used to obtain constant weight. (Table 1)

Table 1:- Bambusa assamica, moisture content percentage.

\begin{tabular}{|l|l|l|l|l|l|}
\hline $\begin{array}{l}\text { Sample } \\
\text { no. }\end{array}$ & $\begin{array}{l}\text { Weight of sample } \\
\text { (in gm.) }\end{array}$ & $\begin{array}{l}\text { Weight of sample } \\
\text { after drying (in gm.) }\end{array}$ & $\begin{array}{l}\text { Difference } \\
\text { in weight (in gm) }\end{array}$ & $\begin{array}{l}\text { Moisture } \\
\text { content \% }\end{array}$ & $\begin{array}{l}\text { Average of moisture } \\
\text { content \% }\end{array}$ \\
\hline 2.1 & 2.9892 & 1.6623 & 1.3269 & 44.389803 & \\
\hline 2.2 & 3.3743 & 1.8175 & 1.5568 & 46.136977 & \\
\hline 2.3 & 4.0331 & 2.1885 & 1.8446 & 45.73653 & $45.1444 \pm 0.92$ \\
\hline 2.4 & 2.8517 & 1.5978 & 1.2539 & 43.970263 & \\
\hline 2.5 & 2.8994 & 1.5805 & 1.3189 & 45.488721 & \\
\hline
\end{tabular}

\section{Alcohol-tolune solubility:-}

Soxhlet extraction was done by using around $2 \mathrm{gm}$ oven dried bamboo sample. The solution used was 2:1 solution of ethyl alcohol (92\%) and Toluene respectively. Six (6) siphoning/ hours for eight (8) hours were done. Content was oven dried at $103 \pm 20 \mathrm{C}$ and weight (Table 2). 
Table 2:- Bambusa assamica, Alcohol-tolune solubility.

\begin{tabular}{|l|l|l|l|l|l|l|}
\hline $\begin{array}{l}\text { Sample } \\
\text { no. }\end{array}$ & $\begin{array}{l}\text { Weight of test } \\
\text { sample(gms.) }\end{array}$ & $\begin{array}{l}\text { Weight of glass } \\
\text { crucible(gms.) }\end{array}$ & $\begin{array}{l}\text { Weight of glass } \\
\text { crucible+extract } \\
\text { residue (gms.) }\end{array}$ & $\begin{array}{l}\text { Weight } \\
\text { of } \\
\text { extract } \\
\text { residue }\end{array}$ & $\begin{array}{l}\text { Alcohol- } \\
\text { tolune } \\
\text { soluble\% }\end{array}$ & $\begin{array}{l}\text { Average } \\
\text { alcohol-toluene } \\
\text { soluble } \%\end{array}$ \\
\hline 1.1 & 2.0015 & 17.4173 & 17.526 & 0.1087 & 5.430926 & $5.95731 \pm 0.36$ \\
\hline 1.2 & 2.0053 & 17.4184 & 17.5394 & 0.121 & 6.034009 \\
\hline 1.3 & 2.0015 & 17.4065 & 17.5356 & 0.1291 & 6.450162 \\
\hline 1.4 & 2.0053 & 17.4065 & 17.5241 & 0.1176 & 5.864459 \\
\hline 1.5 & 2.001 & 17.4065 & 17.5267 & 0.1202 & 6.006996 & \\
\hline
\end{tabular}

Water solubility percentage:-

Around 2gm of oven dried bamboo sample was mixed with $100 \mathrm{ml}$ of distilled water into a Erlenmeyer flask. The flask was gently boiled into a water bath for 3 hours by attaching condenser to the flask. The filtrate was oven dried at $103 \pm 2^{0} \mathrm{C}$ and measured (Table 3).

Table 3:- Bambusa assamica, water solubility percentage.

\begin{tabular}{|l|l|l|l|l|}
\hline $\begin{array}{l}\text { No. of } \\
\text { sample }\end{array}$ & $\begin{array}{l}\text { Weight of oven dried } \\
\text { bamboo sample(gm) }\end{array}$ & $\begin{array}{l}\text { Weight of water soluble } \\
\text { content of bamboo }(\mathrm{gm})\end{array}$ & $\begin{array}{l}\text { Percentage of water } \\
\text { soluble content }(\%)\end{array}$ & $\begin{array}{l}\text { Average of water } \\
\text { soluble \% }\end{array}$ \\
\hline 1.1 & 2 & 0.1486 & 7.43 & $7.634 \pm 0.39$ \\
& 2.2 & 2 & 0.1665 & 8.325 \\
\\
\hline 1.3 & 2 & 0.151 & 7.55 & \\
\hline 1.4 & 2 & 0.15 & 7.5 & \\
\hline 1.5 & 2 & 0.1473 & 7.365 & \\
\hline
\end{tabular}

Ash content percentage:-

Around $2 \mathrm{gm}$ of oven dried bamboo sample was igniting in the muffle furnace until all the carbon was removed. The heating was slowly and increases up to the final heating $580^{\circ} \mathrm{C}$ to $600^{\circ} \mathrm{C}$ (Table 4).

Table 4:- Bamboosa assamica, ash content percentage of.

\begin{tabular}{|l|l|l|l|l|}
\hline $\begin{array}{l}\text { No. } \\
\text { sample }\end{array}$ & $\begin{array}{l}\text { Weight of oven dried } \\
\text { bamboo sample(gm) }\end{array}$ & $\begin{array}{l}\text { Weight of ash } \\
\text { content of } \\
\text { bamboo }(\mathrm{gm})\end{array}$ & $\begin{array}{l}\text { Percentage of ash } \\
\text { content }(\%)\end{array}$ & Average of ash content \% \\
\hline 1.1 & 2.0139 & 0.0216 & 1.072545 & \\
\hline 1.2 & 2.0068 & 0.0209 & 1.041459 & $1.031786 \pm 0.03$ \\
\hline 1.3 & 2.0045 & 0.0198 & 0.987777 & \\
\hline 1.4 & 2.0048 & 0.02 & 0.997605 & \\
\hline 1.5 & 2.0103 & 0.0213 & 1.059543 & \\
\hline
\end{tabular}

Determination of Klason Lignin:-

Around $2 \mathrm{gm}$ of oven dried bamboo sample was taken in to a beaker of $150 \mathrm{ml}$. the sample was mixed with $15 \mathrm{ml}$ of $\mathrm{H}_{2} \mathrm{SO}_{4}(72 \%)$ slowly. The reaction was allowed to continue for 2 hours by placing the whole set into a water both maintained at $20^{\circ} \mathrm{C}$. After the 2 hours reaction $560 \mathrm{ml}$ of distilled water was added to dilute the $\mathrm{H}_{2} \mathrm{SO}_{4}$. The whole set up was placed in a boiling water bath, during the process a glass condenser was added to the flask. The content of the flask was collected and oven dried at $103 \pm 2{ }^{\circ} \mathrm{C}$ (Table 5).

Table 5:- Bamboosa assamica, Klason Lignin content percentage.

\begin{tabular}{|l|l|l|l|l|l|}
\hline $\begin{array}{l}\text { No. } \\
\text { sample }\end{array}$ & $\begin{array}{l}\text { Weight of oven dried } \\
\text { bamboo sample(gm) }\end{array}$ & $\begin{array}{l}\text { Weight } \\
\text { extracted } \\
\text { bamboo sample } \\
(\mathrm{gm})\end{array}$ & $\begin{array}{l}\text { Percentage of } \\
\text { Klason } \\
\text { content }(\%)\end{array}$ & $\begin{array}{l}\text { Average of of Klason } \\
\text { Lignin \% }\end{array}$ \\
\hline 1.1 & 0.3109 & & 15.545 & $15.38122 \pm 0.43$ \\
\hline 1.2 & 2.0013 & 0.3033 & & 15.1551 & \\
\hline 1.3 & 2.002 & 0.2985 & & 16.91 & \\
\hline 1.4 & 2.002 & 0.3214 & & 15.2421 & \\
\hline 1.5 & 2.003 & 0.3053 & & \\
\hline
\end{tabular}




\section{Determination of Holocellulose content:-}

Dried bamboo sample (around $2 \mathrm{gms}$.) was taken into a $250 \mathrm{ml}$ Erlenmeyer flask. The sample was added with $150 \mathrm{ml}$ of distilled water, $0.2 \mathrm{ml}$ of glacial acetic acid and $1 \mathrm{gm}$ of $\mathrm{NaClO}_{2}$. After mixing well the whole set up was placed into a water bath maintaining at $70^{\circ} \mathrm{C}$. The reaction was allowed to continue for about 5 hours. After the reaction the flask was cooled at ice water to lower the temperature to $10^{\circ} \mathrm{C}$. The content of the flask was filtered and washed with cold water (500ml) to make the content free of $\mathrm{ClO}_{2}$ then oven dried at $103 \pm 2^{\circ} \mathrm{C}$ (Table 6).

Table 6:- Bamboosa assamica, Holocellulose content percentage.

\begin{tabular}{|l|l|l|l|l|}
\hline $\begin{array}{l}\text { No. } \\
\text { sample }\end{array}$ & $\begin{array}{l}\text { Weight of oven dried } \\
\text { bamboo sample(gm) }\end{array}$ & $\begin{array}{l}\text { Weight of extracted } \\
\text { bamboo sample }(\mathrm{gm})\end{array}$ & $\begin{array}{l}\text { Percentage } \\
\text { Holocellulose content }(\%)\end{array}$ & $\begin{array}{l}\text { Average } \\
\text { Holocellulose \% }\end{array}$ \\
\hline 1.1 & 2.0005 & 1.082 & 54.0864 & \\
\hline 1.2 & 2.0015 & 1.1323 & 56.5725 & $55.88172 \pm 1.18$ \\
\hline 1.3 & 2.0015 & 1.115 & 55.7082 & \\
\hline 1.4 & 2.0012 & 1.1459 & 57.2606 & \\
\hline 1.5 & 2.0014 & 1.1164 & 55.7809 & \\
\hline
\end{tabular}

Determination of $\alpha$-cellulose content:-

Around $2 \mathrm{gms}$ of oven dried holocellulose sample was taken into a $250 \mathrm{ml}$. Erlenmeyer flask and added and mixed with $50 \mathrm{ml}$ of $\mathrm{NaOH}(17.5 \%)$ and allowed to reaction. After few minutes of reaction a $50 \mathrm{ml}$ of distilled water was added and mixed well. The whole setup was carried out into a water bath maintained at $20 \mathrm{oC}$. The filtrate was washed with $50 \mathrm{ml} \mathrm{NaOH}(8.3 \%)$ and then $40 \mathrm{ml}$. Acetic acid (10\%) and finally washed with hot water to make the content acid free. The content was oven dried at $103 \pm 2^{\circ} \mathrm{C}$ (Table 7).

Table 7:- Bambusa assamica, $\alpha$-cellulose content percentage

\begin{tabular}{|l|l|l|l|l|}
\hline $\begin{array}{l}\text { No. of } \\
\text { sample }\end{array}$ & $\begin{array}{l}\text { Weight of oven dried } \\
\text { holocellulose sample(gm) }\end{array}$ & $\begin{array}{l}\text { Weight of extracted } \\
\text { bamboo sample (gm) }\end{array}$ & $\begin{array}{l}\text { Percentage of } \begin{array}{c}\text { A- } \\
\text { cellulose content (\%) }\end{array} \\
\text { cellulose \% }\end{array}$ \\
\hline 1.1 & 2.0012 & 0.7519 & 37.5724 & \\
\hline 1.2 & 2.0014 & 0.762 & 38.0733 & \\
\hline 1.3 & 2.001 & 0.7569 & 37.826 & $36.5416 \pm 1.78$ \\
\hline 1.4 & 2.0002 & 0.6853 & 34.2615 & \\
\hline 1.5 & 2 & 0.6995 & 34.975 & \\
\hline
\end{tabular}

Analysis of trace element:-

The importance of certain element in the physical and anatomical structure is studied. In this study the elements $\mathrm{Ca}$, $\mathrm{Mn}, \mathrm{K}, \mathrm{Mg}$ and $\mathrm{Zn}$ are studied. Ash analysis through trace element analysis by Graphite Furnace-Atomic Absorption Spectrometer was adopted.

\section{Study of Anatomical characters:-}

\section{Study of vascular bundle:-}

To study the vascular bundle of the bamboo sample a 45micron thick transverse section was cut with a microtome machine and a temporary permanent preparation was done with aqueous safranin stain. The section was dried in the oven at $40^{\circ} \mathrm{C}$ for 8 hours.

To determine the concentration of vascular bundle the prepared slide was observed under a light compound microscope at $5 \mathrm{X}$ magnification. The viewed area of each slide was divided into three horizontal layers, outer, middle and inner (Fig 1). In every cross section the number of the vascular bundle was counted and the area from which the bundle was counted was measured.

Measurement of the vascular bundle was done by using the same slide focused under light microscope at 10X magnification. The measurement of the vascular bundle was done from randomly selected vascular bundle from the focused area by using camera fitted microscope and ScopeImage 9.0(HIC) software. During measurement of the vascular bundle care was taken that the shorter and longer vascular bundle was not noted down. And according to the three layers of the cross section of the slide the noted length of the vascular bundle was range $70 \mu \mathrm{m}$ to $76 \mu \mathrm{m}$ for outer layer, $77 \mu \mathrm{m}$ to $82 \mu \mathrm{m}$ for middle layer and $83 \mu \mathrm{m}$ to $89 \mu \mathrm{m}$ for inner layer. Vascular bundle shorter than and longer than this for each layer of the section was discarded (not noted down).Care was taken to discard the repeated length of vascular bundle during calculation. 15numbers of slide was prepared for each sample; altogether 75 slide was studied for 5numbers of individual bamboo sample (Fig 1) and (Fig 2), ScopeImage 9.0(HIC) software (at 
10Xmagnification).Summary of Average vascular bundle concentration within $4 \mathrm{~mm}^{2}$ (Table 8); Summary of average vascular bundle length (Table 9). The result of the vascular bundle length as in table was shown that the maximum length was in inner layer of the cross section and decreasing towers middle and outer layer.

Table 8:- Bambusa assamica, average vascular bundle concentration.

\begin{tabular}{|c|c|c|}
\hline Sl.no. & Possition & Average concentration of vascular bundle \\
\hline 1 & Outer & $5.24 \pm 0.26$ \\
\hline 2 & Middle & $3.68 \pm 0.26$ \\
\hline 3 & Inner & $3.36 \pm 0.16$ \\
\hline
\end{tabular}

Table 9:- Bambusa assamica, average vascular bundle length.

\begin{tabular}{|c|c|c|}
\hline Sl.no. & Position & Average length of vascular bundle in $\mu \mathrm{m}$ \\
\hline 1 & Outer & $75.1783 \pm 0.32$ \\
\hline 2 & Middle & $78.8244 \pm 0.64$ \\
\hline 3 & Inner & $85.9296 \pm 0.80$ \\
\hline
\end{tabular}

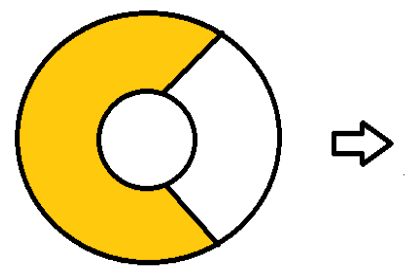

[A]

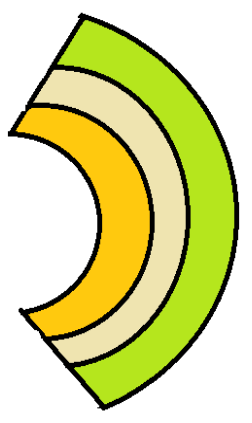

[B]

\section{O Outer}

Middle

Inner

Fig 1, Plane for cutting of cross sectional slide, [A] Showing outline of bamboo internode, [B] Cross sectional plane for section.

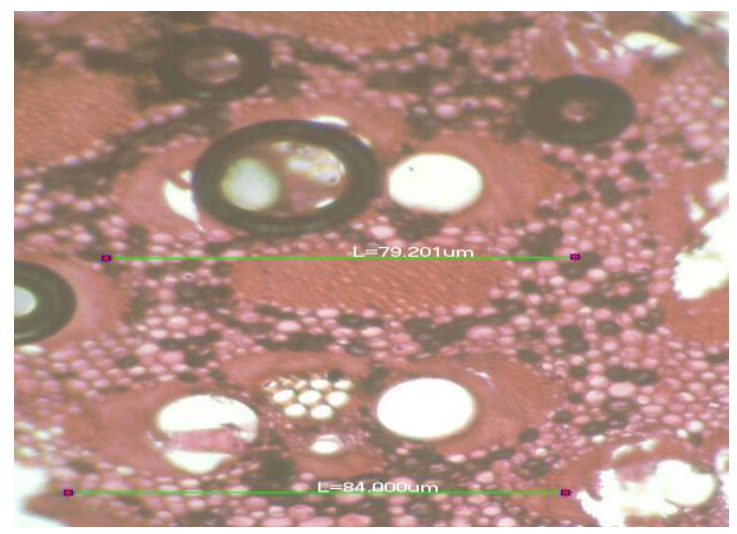

Photo1, Measurement of vascular bundle

Measurement of fibre length:-

Macerated bamboo fibre was measured. The sample is first cut into small pieces of $0.25 \times 0.25 \times 5 \mathrm{~cm}$. The pieces of samples are macerated with the maceration solution of Glacial acetic acid, $30 \%$ hydrogen peroxide and distilled water in ratio 5:1:4 respectively. The time for maceration is 48 hours at $60^{\circ} \mathrm{C}$. The randomly selected fibre from the 
focused area was measured by using camera fitted microscope and ScopeImage 9.0(HIC) software. The repeated length of fibre was not noted down for calculation (Table10).

Table 10:- Bambusa assamica, average fibre length.

\begin{tabular}{|c|c|c|c|}
\hline Sample no. & Total no of fibre measured & Average Fibre length in $\mu \mathrm{m}$ & Total average fibre length \\
\cline { 2 - 4 } & & 2.009 & $\mu \mathrm{m}$ \\
\hline 2.1 & $25 \mathrm{nos}$ & 1.9 & \\
\hline 2.2 & $25 \mathrm{nos}$ & 2.089 & $1.995 \pm 0.06$ \\
\hline 2.3 & $25 \mathrm{nos}$ & 2.007 & \\
\hline 2.4 & $25 \mathrm{nos}$ & 1.97 & \\
\hline 2.5 & $25 \mathrm{nos}$ & & \\
\hline
\end{tabular}

\section{Result and Discussions:-}

Result of the chemical content of Bambusa assamica is as in the table (Table 11); Results of Bambusa assamica, Trace Element analysis by Graphite Furnace-Atomic Absorption Spectrometer (GF-AAS, Analytik Jena Vario-6), under concentration in ppm (parts per million) is as shown in (Table 12). Result of the anatomical characters of

Bambusa assamica is shown in (Table 13).

Table 11:- Bambusa assamica, chemical content.

\begin{tabular}{|l|l|l|l|l|l|l|l|}
\hline $\begin{array}{l}\text { Sample } \\
\text { no. }\end{array}$ & $\begin{array}{l}\text { Moisture } \\
\text { content } \%\end{array}$ & $\begin{array}{l}\text { Alcohol-tolune } \\
\text { solubility \% }\end{array}$ & $\begin{array}{l}\text { Hot water } \\
\text { solubility \% }\end{array}$ & $\begin{array}{l}\text { Ash } \\
\text { content \% }\end{array}$ & Lignin\% & $\begin{array}{l}\text { Holocellulo } \\
\text { se \% }\end{array}$ & $\begin{array}{l}\alpha- \\
\text { cellulose } \%\end{array}$ \\
\hline $\begin{array}{l}\text { Bambusa } \\
\text { assamica, }\end{array}$ & $45.14 \pm 0.9$ & $5.95 \pm 0.36$ & $7.63 \pm 0.39$ & $1.03 \pm 0.03$ & $15.38 \pm 0.43$ & $55.88 \pm 1.18$ & $36.54 \pm 1.78$ \\
\hline
\end{tabular}

Table 12:- Bambusa assamica ,trace element analysis.

\begin{tabular}{|c|c|c|c|c|c|c|}
\hline Sl.no. & Sample no. & & & & Elemen & \\
\hline \multirow[t]{2}{*}{1} & \multirow[t]{2}{*}{$\begin{array}{c}\text { B. } \\
\text { assamica. }\end{array}$} & $\mathbf{C a}$ & Mn & $\mathbf{K}$ & Mg & $\mathbf{Z n}$ \\
\hline & & $\begin{array}{c}4.87+- \\
0.61\end{array}$ & $\begin{array}{c}0.31+- \\
0.03\end{array}$ & $\begin{array}{c}30.32+- \\
2.01\end{array}$ & $\begin{array}{c}11.01+- \\
0.01\end{array}$ & $0.20+-0.03$ \\
\hline
\end{tabular}

Table 13:- Bambusa assamica, anatomical characters.

\begin{tabular}{|c|c|c|c|c|}
\hline Sl.no. & Position & $\begin{array}{c}\text { Average concentration of } \\
\text { vascular bundle }\end{array}$ & $\begin{array}{c}\text { Average length of vascular } \\
\text { bundle in } \mu \mathrm{m}\end{array}$ & Total average fibre length \\
\cline { 1 - 4 } & Outer & $5.24 \pm 0.26$ & $75.17 \pm 0.32$ & in $\mu \mathrm{m}$ \\
\hline 2 & Middle & $3.68 \pm 0.26$ & $78.82 \pm 0.64$ & $1.99 \pm 0.06$ \\
\hline 3 & Inner & $3.36 \pm 0.16$ & $85.92 \pm 0.80$ & \\
\hline
\end{tabular}

This result of study on Physico-chemical and anatomical composition of Bambusa assamica help in knowing of important content of this less utilised bamboo species which make it suitable for various application and substitution of forest based cellulose wood in near future.

Average ash content (1.031786 \pm 0.03$)$ of this bamboo species is under desirable range for pulping, as high ash content is undesirable due to its effect on normal alkali consumption and operational problem like pulp beating and washing.

The Hot water solubility $\%$ in this bamboo that is found during the study was $7.63 \pm 0.39$. This figure shows comparatively low water solubility which is one of the important characteristics for better utility of a bamboo, as higher is the water solubility the lower will be the pulp yield. 
The fibre length is important for the strength of bamboo. It is also important for pulp and paper making, as greater the fiber length, the higher will be the tearing resistance of paper. This study tells that Bambusa assamica has comparatively good fibre length, just near to $2 \mu \mathrm{m}$. The deposition of the element tells about the hardness of the bamboo, this bamboo has good deposition of important elements. The Ca content of this bamboo is very good with $4.8 \mathrm{ppm}$. Likewise $\mathbf{K}$ and $\mathbf{M g}$ content with around 30ppm. and 11ppm. respectively.

The result of the vascular bundle length as in table was shown that the maximum length was in inner layer of the cross section and decreasing towers middle and outer layer.

\section{Conclusions:-}

India is the second highest bamboo producing country in the world. Based on taxonomic descriptions, there are 18 genera and128 species of bamboo in India. Out of these bamboo species 13 sympodial bamboo species belonging to 7 genera has recommended for traditional as well as industrial applications by the National Bamboo Mission (NBM), Govt. of India. The Bamusa assamica which is yet to include in this list have needed much more study.

The Bambusa assamica can be easily cultivated in this part of the country and can be renewed within one and half year of time. Although this bamboo is presently used in many traditional applications but this study tells another aspect of its utility. Since this bamboo is having important content that is not much lesser than other regularly used bamboo species. The study concluded that along with the traditional basketry uses this bamboo can also be recommend for variety of industrial uses.

\section{Acknowledgements:-}

We would like to thank Dr.Sandeep Das, HOD, Biotechnology, Bodoland University for providing facilities in support for the work. Thanks are expressed to Dr. R.N. Shinha Principal Science College, Kokrajhar for allowing us to carry out some part of the experiment at laboratory of Science College, Kokrajhar. We also acknowledge the help of Mr. Kailash Barman of CIT, Kokrajhar. Thanks to all friends and well wisher for their kind help and cooperation.

\section{References:-}

1. M. Azmy, J.B. Hall, S. Othman, W. Razak, A.B.K. Rashidah, Quality management of the bamboo resource and its contribution to environmental conservation in Malaysia,Management of Environmental Quality, An International Journal, 18(6), 2007, pp 643-656.

2. C. Barooah , S.K. Borthakur. 2003. Diversity and distribution of bamboos in Assam. M/s Bishen Sing Mahendra Pal Singh,Dehra Dun.

3. S. Biswas, Studies on bamboo distribution in north eastern region of india. Indian Forester 114, 1988, pp. 514531.

4. S. Biswas, On the occurrence of Bambusa burmanica Gamble in India. Indian J. Forestry 16(1), 1993, pp.7576.

5. S.Brahma, B.K. Brahma. Bambusa garuchokua the less utilised bamboo of Assam and North-East India,International Journal of Innovative Research in Science Engineering and Technology, 4( 6), 2015, pp. 4122-4127

6. J.J.A Janssen, The relationship between the mechanical properties and the biological and chemical composition of bamboo. In: Higuchi, T.(ed.). Bamboo production and utilisation. Proceedings of the Congress Group 5.3A on IUFRO World Congress, Kyoto,Japan, 6-17 September 1981.

7. K. Kawase, Distribution and utilityvalue of Sasa bamboo. In: Higuchi, T.(ed.). Bamboo production and utilisation. Proceedings of the Congress Group 5.3A on IUFRO World Congress, Kyoto,Japan, 617 September 1981.

8. W. Liese, Anatomy and properties of bamboo. Recent research on Bamboo, Ed.:Chino Acad. Of forestry, Peking, and IDRC, Canada. 1987, 196-208

9. M. T. Mustafa, W.Razak, S.Mahmud, Othman Sulaiman, Nurul Ain' Mohd Kamal, Izyan Khalid.. Anatomical and Microstructures Features of Tropical Bamboo, Gigantochloa brang, G. levis, G. scotechinii and G. wrayi, Int. J. Forest, Soil and Erosion, 1(1), 2011, 25-35.

10. A.K. Sharma, D. Dutt, J.S. Upadhyaya ,T.K.Roy. Bambusa spp. \& papermaking. BioResources 6(4), 2011 , Pp. 5062-5073.

11. D.N. Tewari , A monograph on Bamboo. International book Distributors, Dehra Dun, 1992. 